\title{
Evaluation of Novel Antiviral Agents in the Elimination of Satsuma dwarf virus (SDV) by Semi-micrografting in Citrus
}

\author{
Satoshi Ohta ${ }^{1 *}$, Takeshi Kuniga ${ }^{1 * *}$, Fumie Nishikawa ${ }^{1 * * *}$, Atsu Yamasaki ${ }^{1 * * * *}$, \\ Tomoko Endo ${ }^{1}$, Toru Iwanami ${ }^{2}$ and Terutaka Yoshioka ${ }^{1}$ \\ ${ }^{1}$ Okitsu Citrus Research Station, National Institute of Fruit Tree Science, Shizuoka 424-0292, Japan \\ ${ }^{2}$ National Institute of Fruit Tree Science, Tsukuba 305-8605, Japan
}

In fruit trees and vegetative reproductive plants, viral elimination from mother plants is conducted to produce virus- and viroid-free nursery plants. In citrus, shoot tip culture and semi-micrografting combined with thermotherapy were adopted for viral elimination; however, these methods should be modified for ease or higher efficiency. One solution might be the application of effective antiviral agents. In this study, we tested the efficacy of 4 antiviral agents, ribavirin, foscarnet, zidovudine, and enfuvirtide, against Satsuma dwarf virus (SDV) in Citrus unshiu Marc. 'Ueno-wase' to screen effective agents. The results showed that foscarnet had the highest efficacy against SDV at semi-micrografting combined with thermotherapy, and that the efficacy was significantly different from that of the untreated control. On the other hand, ribavirin, which was thought to be efficient against some citrus viruses, has no significant effect against SDV. There were no harmful effects of foscarnet or ribavirin on re-generation. It was considered that the optimization of treatment method and concentration is required before applying ribavirin as an antiviral agent against SDV. Foscarnet was thought to be highly effective against SDV and was also expected to have high efficacy against other plant viruses. Moreover, our results suggested the possibility that other human antiviral agents that have not been investigated in plants could be effective against plant viruses.

Key Words: chemotherapy, citrus, foscarnet, Satsuma dwarf virus, viral elimination.

\section{Introduction}

Many types of viruses infect citrus trees in orchards in Japan and cause serious damage, including deterioration of fruit quality, decreased yield, reduced tree vigor, and withering (Imada et al., 1980; Nomura et al., 2000; Ushiyama, 1982). Once a field tree is infected with viruses or viroids, it is impossible to

Received; May 27, 2010. Accepted; September 15, 2010.

Contribution No. 1573, of National Institute of Fruit Tree Science, NARO.

* Corresponding author (E-mail: sohta@affrc.go.jp).

** Present address: Shikoku Research Center, National Agricultural Research Center for Western Region, Zentsuuji 765-0053, Japan.

*** Present address: Kuchinotsu Citrus Research Station, National Institute of Fruit Tree Science, Minami-shimabara 859-2501, Japan.

**** Present address: Grape and Persimmon Research Station, National Institute of Fruit Tree Science, Higashi-hiroshima 7392494, Japan. completely eliminate these pathogens from that tree. The pathogens often spread to healthy trees in the orchard by grafting and occasionally by pruning, and Citrus tristeza virus is transmitted by aphids (Bennett and Costa, 1949). Moreover, Satsuma dwarf virus (SDV) is suggested to be soil-borne and persistently infests orchards (Izawa, 1966); therefore, it is important to distribute virus- and viroid-free nursery plants and keep them healthy; in fact, many countries are conducting careful certification programs.

To produce healthy nursery trees by eliminating viruses and viroids, shoot tip culture and semimicrografting combined with thermotherapy were developed in citrus plants (Iwanami et al., 1993; Takahara et al., 1986). We can now grow virus- and viroid-free citrus trees of many cultivars and wild genetic resources with a success rate of $25-50 \%$. However, it is very difficult for untrained personnel to achieve high success rates using these methods, because microtechniques and occasional aseptic manipulation are required; therefore, improvement of these methods is 
required to achieve higher success rates.

From this view point, the effect of chemotherapy was actively investigated in the 1980s. Ribavirin has a wide spectrum of antiviral efficacy among DNA and RNA viruses (Sidwell et al., 1972), including Cucumber mosaic virus and Alfalfa mosaic virus (Simpkins et al., 1981), potato viruses (Cassells and Long, 1982), Turnip yellow mosaic virus in cabbage (Kalonji-M'Buyi and Kummert, 1982), Tobacco mosaic virus (Dawson and Lozoya-Saldana, 1984), and Apple chlorotic leafspot virus (Hansen and Lane, 1985). Many theories have been proposed to explain the mode of action of ribavirin (Graci and Cameron, 2005). In citrus, the effect of ribavirin was also shown against Citrus tristeza virus, Citrus variegation virus, Citrus viroid complex (Greño et al., 1990), and Citrus tatter leaf virus (currently redesignated Apple stem grooving virus) (Iwanami and Ieki, 1994; Iwanami et al., 1993). However, chemotherapy is not practically applied for viral elimination in citrus plants because the effect of ribavirin is limited, and its efficacy against SDV, one of the most harmful citrus viruses in Japan, has not been demonstrated. On the other hand, many antiviral agents with different modes of action were discovered after the identification of Human immunodeficiency virus 1 (HIV-1). Recently, some of these new antiviral agents have become more readily available; for example, it was reported that foscarnet, which binds directly to RNA polymerase and DNA polymerase of many viruses and inhibits their activities (Öberg, 1989), has an antiviral effect on several viruses (Helgstrand et al., 1978). One of the first antiviral agents for HIV-1, 3'-azido-3'-deoxythymidine (zidovudine), was found in 1985 (Mitsuya et al., 1985). Zidovudine has high absorbability and permeability in human tissue (Bean, 1992) and inhibits the reverse transcriptase of HIV-1 (Mitsuya et al., 1985). T-20 (enfuvirtide), which blocks cell fusion and viral entry of HIV-1, was found in 1998 (Kilby et al., 1998) and was approved in the USA in 2003. However, most of these new antiviral agents have never been used for chemotherapy in plants, except for some studies in Vitis vinifera (Panattoni et al., 2007a, b); therefore, it is expected that some of these new antiviral agents may have great efficacy against some specific plant viruses.

In this study, we tested 4 antiviral agents (ribavirin, foscarnet, zidovudine and enfuvirtide), which have different modes of action and features, on citrus plants infected with SDV and discussed their possible use for viral elimination.

\section{Materials and Methods}

\section{Antiviral treatment and semi-micrografting}

A potted citrus tree (Citrus unshiu Marc. 'Ueno-wase') infected with SDV (SDV-S-58; Iwanami et al., 2001) was used to collect the shoots. The branches of this infected tree were divided into 5 parts, 4 were treated with each of the 4 antiviral agents and 1 was untreated (control).
To promote shoot elongation, long branches were cut back to two-thirds of the original length, about half of the leaves were removed, and 6-benzylaminopurine $(0.03 \%)$ was sprayed on the remaining leaves. Subsequently, the tree was treated with thermotherapy consisting of 2 temperature conditions, $35^{\circ} \mathrm{C}(6: 00-18: 00)$ and $30^{\circ} \mathrm{C}$ (18:00-6:00) through experimentation. The 4 antiviral agents, ribavirin (MP Biomedicals LLC., USA), foscarnet (sodium phosphonoformate hexahydrate, CAS No. 34156-56-4 is identical to trisodium phosphonoformate) (Alfa Aesar, USA), zidovudine (The United States Pharmacopeial Convention, USA), and enfuvirtide (Prospec-Tany Technogene Ltd., Israel), were dissolved in distilled water at $100 \mathrm{ppm}, 1000 \mathrm{ppm}$, $50 \mathrm{ppm}$, and $30 \mathrm{ppm}$, respectively. Except for ribavirin, the concentrations of these agents were decided with reference to the doses applied in humans because there was no precedent application to plants, and their optimal concentrations were unknown. Ribavirin was used at a concentration of $100 \mathrm{ppm}$ according to a previous report of its use in citrus plants (Iwanami et al., 1993). Antiviral agents were applied on the surface of elongating shoots with absorbent cotton 3 times a week (Monday, Wednesday, and Friday) throughout the experiment. Shoots that elongated to $2-4 \mathrm{~cm}$ were picked each day for about 3 months, and were used for semimicrografting. According to the method by Takahara et al. (1986), $0.3 \mathrm{~mm}$ of the shoot tip was grafted onto the epicotyl of the general root stock species, Poncirus trifoliata (L.) Raf., and grown in a room at $27^{\circ} \mathrm{C}$.

\section{Estimation of the efficacy of each antiviral agent}

In the initial screening test of 4 antiviral agents, the presence of SDV after treatment with antiviral agents was examined using SDV Chromato (Mizuho Medy Co, Ltd., Japan), a kit for assaying SDV based on the immune chromatography method (Kusano et al., 2007). About 2 months after a shoot tip was grafted, new leaves emerging from the shoot tip were collected and checked with SDV Chromato following the manufacturer's instructions. Positive reactions were confirmed by the band seen on the test line of the chromatograph.

On the other hand, in the additional experiment of ribavirin and foscarnet, the presence of SDV was confirmed by reverse transcription polymerase chain reaction (RT-PCR), which is thought to have higher sensitivity than SDV Chromato. Total RNA was extracted from $50 \mathrm{mg}$ of each leaf sample using ISOGEN (Nippon Gene Co, Ltd., Japan). Finally, the RNA concentration was adjusted to $200 \mathrm{ng} / \mu \mathrm{l}$. Reverse transcription was performed using a TaKaRa RNA PCR Kit (AMV) Ver. 3.0 (Takara, Japan) according to the manufacturer's instructions, except that Random 9-mers was exchanged for $5 \mu \mathrm{M}$ of Random Hexamer Primer (Fermentas Life Sciences, Lithuania). The program for reverse transcription consisted of one cycle at $23^{\circ} \mathrm{C}$ for $10 \mathrm{~min}, 42^{\circ} \mathrm{C}$ for $30 \mathrm{~min}, 99^{\circ} \mathrm{C}$ for $5 \mathrm{~min}$, and $5^{\circ} \mathrm{C}$ for 
5 min. After the reaction, the cDNA product was diluted 5-fold with distilled water. Subsequently, PCR amplification was performed in a $10 \mu \mathrm{l}$ solution of $1 \times \mathrm{PCR}$ Gold Buffer (Applied Biosystems, Life Technologies, USA), $2.5 \mathrm{mM} \mathrm{MgCl} 2,0.16 \mathrm{mM}$ of each dNTP, $8 \mathrm{pM}$ of each primer, 0.25 units of AmpliTaq Gold DNA Polymerase (Applied Biosystems, Life Technologies), and $2 \mu \mathrm{l}$ of the diluted cDNA product. Forward primer (FW146: 5'-ACTAGGGATAGCGCCCTAG-3') and reverse primer (RV448: 5'-GGACCGATATTGGGCCAT3') were designed from conserved sequences among SDV strains (Iwanami, 2010). The PCR program consisted of an initial denaturation for $9 \mathrm{~min} 30 \mathrm{~s}$ at $94^{\circ} \mathrm{C}$; followed by 40 cycles of $30 \mathrm{~s}$ at $94^{\circ} \mathrm{C}, 50^{\circ} \mathrm{C}$, and $72^{\circ} \mathrm{C}$; and a final extension of $5 \mathrm{~min}$ at $72^{\circ} \mathrm{C}$. PCR products were electrophoresed on a $5 \%$ acrylamide gel and stained with ethidium bromide.

The efficacy of each antiviral agent was estimated using 2 success rate formulas. One determined the virusfree rate (the number of virus-free individuals divided by the number of individuals producing at least 1 new leaf from the grafted shoot tip), and the other determined the total success rate (the number of virus-free individuals divided by the number of shoot tips grafted on root stocks for each antiviral agent). Statistical analysis was performed using Fisher's exact test (Yates, 1984).

\section{Results and Discussion}

In the screening tests, rates of regenerated plantlets (regeneration rate) with the application of three antiviral agents (ribavirin, foscarnet, and zidovudine) and a control ranged from $50 \%$ to $67 \%$, although enfuvirtide showed a slightly lower rate $(40 \%)$ (Table 1$)$. The results suggested that ribavirin, foscarnet, and zidovudine had no harmful effects, although enfuvirtide may slightly affect regeneration. In the SDV detection assay, applications of ribavirin and foscarnet showed higher virus-free rates (100\% and $90 \%$, respectively) than the control (81\%), whereas zidovudine and enfuvirtide showed lower virus-free rates $(50 \%$ and $25 \%$, respectively) than the control (Table 1). In the total success rate, the two antiviral agents, ribavirin and foscarnet, were also found to be more effective than the others (Table 1). In this study, we could not test the antiviral agents using optimal concentrations owing to the lack of antiviral precedents in plants, except for ribavirin. Antiviral agents used at higher concentrations (foscarnet, $1000 \mathrm{ppm}$; ribavirin, $100 \mathrm{ppm}$ ) apparently showed higher success rates than those using lower concentrations (zidovudine, $50 \mathrm{ppm}$; enfuvirtide, $30 \mathrm{ppm}$ ); this trend was also seen in other studies (Greño et al., 1990; Iwanami and Ieki, 1994; Kalonji-M'Buyi and Kummert, 1982; Simpkins et al., 1981). Therefore, it could not be concluded that zidovudine and enfuvirtide were inefficient against SDV. On the other hand, we observed that the elongating speeds of the shoots applied with zidovudine and enfuvirtide were slower than that of the control. It was considered that the applications of antiviral agents in this unoptimized treatment method and the concentration might have an opposite effect on viral elimination. Nevertheless, as a result of this screening test, we could select ribavirin and foscarnet as candidate antiviral agents against SDV and conduct an additional investigation to clarify the efficacy of each in more detail.

In further investigation, regeneration rates with the application of ribavirin, foscarnet, and the control were $68.0,71.7$, and $54.4 \%$, respectively, suggesting that these two antiviral agents had no hamful effects, as described above (Table 2). Virus detection by RT-PCR assay showed that the virus-free rate of forscarnet $(84.2 \%)$ was significantly higher than those of ribavirin and the control ( $P=0.020$ and 0.009 , respectively), which were similar (58.8\% and $54.8 \%$, respectively) (Table 2$)$. Similarly, foscarnet application had the highest total success rate $(60.4 \%)$, significantly different from the control $(P=$ $0.002)$, but no significant differences were found between ribavirin and the control $(P=0.312)$.

Ribavirin did not show significantly higher antiviral efficacy against SDV than the control in this experimental condition (Table 2), although this antiviral agent has been reported to be effective against Citrus tristeza virus, Citrus variegation virus, and Citrus excortis viroid (Bellés et al., 1986; Greño et al., 1990; Iwanami et al., 1993). In fact, virus-free buds were

Table 1. Effectiveness of four antiviral agents on the production of SDV-free re-generated plantlets by semi-micrografting ${ }^{2}$.

\begin{tabular}{|c|c|c|c|c|c|c|c|}
\hline \multirow{2}{*}{ Antiviral agent } & \multirow{2}{*}{$\begin{array}{l}\text { Concentration } \\
(\mathrm{ppm})\end{array}$} & \multirow{2}{*}{$\begin{array}{c}\text { Total no. of } \\
\text { grafted shoot tips }\end{array}$} & \multicolumn{2}{|c|}{ No. of re-generated plantlets ${ }^{y}$} & \multirow{2}{*}{$\begin{array}{c}\text { Re-generated rate } \\
(\%)\end{array}$} & \multirow{2}{*}{$\begin{array}{l}\text { Virus-free rate } \\
(\%)^{\mathrm{x}}\end{array}$} & \multirow{2}{*}{$\begin{array}{c}\text { Total success rate } \\
(\%)^{\mathrm{w}}\end{array}$} \\
\hline & & & Virus-free & Virus-present & & & \\
\hline Ribavirin & 100 & 12 & 8 & 0 & 67 & 100 & 67 \\
\hline Foscarnet & 1000 & 18 & 9 & 1 & 56 & 90 & 50 \\
\hline Zidovudine & 50 & 14 & 4 & 4 & 57 & 50 & 29 \\
\hline Enfuvirtide & 30 & 10 & 1 & 3 & 40 & 25 & 10 \\
\hline Control & - & 32 & 13 & 3 & 50 & 81 & 41 \\
\hline
\end{tabular}

z SDV was checked by SDV Chromato.

${ }^{y}$ No. of the individuals which produced at least one new leaf from the grafted shoot tip.

${ }^{x}$ No. of virus-free plantlets divided by the no. of re-generated plantlets.

${ }^{w}$ No. of virus-free plantlets divided by the no. of grafted shoot tips. 
Table 2. Comparison of the effectiveness of ribavirin and foscarnet on the production of SDV-free re-generated plantlets by semi-micrografting ${ }^{z}$.

\begin{tabular}{|c|c|c|c|c|c|c|c|}
\hline \multirow{2}{*}{ Antiviral agent } & \multirow{2}{*}{$\begin{array}{l}\text { Concentration } \\
(\mathrm{ppm})\end{array}$} & \multirow{2}{*}{$\begin{array}{c}\text { Total no. of } \\
\text { grafted shoot tips }\end{array}$} & \multicolumn{2}{|c|}{ No. of re-generated plantlets } & \multirow{2}{*}{$\begin{array}{c}\text { Re-generated rate } \\
(\%)\end{array}$} & \multirow{2}{*}{$\begin{array}{l}\text { Virus-free rate } \\
(\%)^{\mathrm{x}}\end{array}$} & \multirow{2}{*}{$\begin{array}{l}\text { Total success rate } \\
(\%)^{\mathrm{w}}\end{array}$} \\
\hline & & & Virus-free & Virus-present & & & \\
\hline Ribavirin & 100 & 50 & 20 & 14 & 68.0 & $58.8 \mathrm{a}^{\mathrm{v}}$ & $40.0 \mathrm{a}$ \\
\hline Foscarnet & 1000 & 53 & 32 & 6 & 71.7 & $84.2 \mathrm{~b}$ & $60.4 \mathrm{~b}$ \\
\hline Control & - & 57 & 17 & 14 & 54.4 & $54.8 \mathrm{a}$ & $29.8 \mathrm{a}$ \\
\hline
\end{tabular}

${ }^{z}$ SDV was checked by RT-PCR.

${ }^{y}$ No. of the individuals which produced at least one new leaf from the grafted shoot tip.

${ }^{x}$ No. of virus-free plantlets divided by the no. of re-generated plantlets.

${ }^{\text {w }}$ No. of virus-free plantlets divided by the no. of grafted shoot tips.

v Different letters in each column show significant difference at $P<0.05$ by Fisher's exact test.

efficiently obtained from Citrus tatter leaf virus-infected trees by spraying ribavirin solution (Iwanami and Ieki, 1994). Ribavirin is thought to be applicable for eliminating many citrus viruses and viroids from citrus trees (Greño et al., 1990; Iwanami and Ieki, 1994; Iwanami et al., 1993). In the screening test checked by SDV Chromato, rivbavirin showed the highest total success rate (Table 1). It is possible that ribavirin reduced the SDV concentration below the diagnostic threshold of SDV Chromato but was still detectable by RT-PCR, which is more sensitive than SDV Chromato. Therefore, it was considered that ribavirin might show efficacy against SDV if the treatment method and the concentration were optimized in a future study. On the other hand, we showed that foscarnet was a highly effective antiviral agent against SDV in this experimental condition (Table 2). This is the first report showing the efficacy of foscarnet against a plant virus. Efficacy, estimated as the success rate of viral elimination, is apparently much higher than in previous chemotherapeutic reports of many plant viruses; therefore, it is expected that more studies will be conducted in many plants to clarify whether foscarnet would be widely applicable as an antiviral agent for many plant species.

Ribavirin showed in vitro activity against many RNA and DNA viruses, including human herpes viruses, Influenza A virus, Influenza B virus, and HIV. The efficacy of ribavirin was also reported against many plant viruses (Cassells and Long, 1982; Dawson and LozoyaSaldana, 1984; Greño et al., 1990; Hansen and Lane, 1985; Iwanami et al., 1993; Simpkins et al., 1981). Foscarnet was suggested to be effective against many viruses, including Human herpesvirus 1, Human herpesvirus 2, Suid herpesvirus 1 (Pseudorabies virus), Bovine herpesvirus 1 (infectious bovine rhinotracheitis virus) and influenza virus (Helgstrand et al., 1978; Stridh and Datema, 1984; Stridh et al., 1979), and it was also used against human cytomegalovirus in AIDS patients (Bean, 1992); therefore, the efficacy of ribavirin and foscarnet against SDV might be explained by the wide spectrum of their activity.

Foscarnet affects both cellular and viral polymerases, but relatively lower concentrations are needed to inhibit viral polymerases than to interfere with cellular polymerases (Bean, 1992). Since only one concentration was tested for each antiviral agent in this study, further investigations, particularly for foscarnet, are need to reveal the relationship between concentration and efficacy. Moreover, other than foscarnet, used in this study, tiazofurin and dihydroxypropyladenine showed inhibitory effects against Vitis viruses in recent studies (Panattoni et al., 2007a, b). It is possible that other human antiviral agents that have not yet been investigated in plants may have efficacy against plant viruses.

\section{Acknowledgments}

The authors are grateful to Dr. K. Ogawa, Dr. H. Matsumoto, Dr. H. Nesumi, and Dr. M. Kita for their valuable suggestions and useful discussion. We also thank Mr. T. Kuriki and Ms. M. Mochizuki for their experimental assistance.

\section{Literature Cited}

Bean, B. 1992. Antiviral therapy: current concepts and practices. Clin. Microbiol. Rev. 5: 146-182.

Bellés, J. M., A. J. Hansent, A. Granell and V. Conejero. 1986. Antiviroid effects of ribavirin on citrus exocortis viroid infection in Gynura aurantiaca DC. Physiol. Mol. Plant Pathol. 28: 61-65.

Bennett, C. W. and A. S. Costa. 1949. Tristeza disease of citrus. J. Agric. Res. 78: 207-237.

Cassells, A. C. and R. D. Long. 1982. The elimination of potato viruses $\mathrm{X}, \mathrm{Y}, \mathrm{S}$ and $\mathrm{M}$ in meristem and explant cultures of potato in the presence of Virazole. Potato Res. 25: 165-173.

Dawson, W. O. and H. Lozoya-Saldana. 1984. Examination of the mode of action of ribavirin against tobacco mosaic virus. Intervirology 22: 77-84.

Graci, J. D. and C. E. Cameron. 2005. Mechanisms of action of ribavirin against distinct viruses. Rev. Med. Virol. 16: 37-48.

Greño, V., M. Cambra, L. Navarro and N. Durán-Vila. 1990. Effect of antiviral chemicals on the development and virus content of citrus buds cultured in vitro. Sci. Hortic. 45: 75-87.

Hansen, A. J. and W. D. Lane. 1985. Elimination of apple chlorotic leafspot virus from apple shoot. Plant Dis. 69: 134-135.

Helgstrand, E., B. Eriksson, N. G. Johansson, B. Lannerö, A. Larsson, A. Misiorny, J. O. Norén, B. Sjöberg, K. Stenberg, G. Stening, S. Stridh, B. Öberg, S. Alenius and L. Philipson. 1978. Trisodium phosphonoformate, a new antiviral compound. Science 201: 819-821.

Imada, J., H. Tanaka and N. Narisawa. 1980. The effect of satsuma dwarf virus and citrus mosaic virus on the growth of citrus 
trees. Bull. Fruit Tree Res. Stn. E 3: 75-82 (In Japanese with English abstract).

Iwanami, T. 2010. Properties and control of Satsuma dwarf virus. JARQ 44: 1-7.

Iwanami, T. and H. Ieki. 1994. Elimination of citrus tatter leaf virus from shoots of potted citrus plants by ribavirin. Ann. Phytopath. Soc. Japan 60: 595-599.

Iwanami, T., T. Hidaka and M. Omura. 1993. Shoot-tip culture of citrus III. Elimination of citrus tatter leaf virus from cultured shoots. Bull. Fruit Tree Res. Stn. 24: 61-71.

Iwanami, T., Y. Kondo, M. Kobayashi, S. S. Han and A. V. Karasev. 2001. Sequence diversity and interrelationships among isolates of satsuma dwarf-related viruses. Arch. Virol. 146: 807-813.

Izawa, H. 1966. Investigation on withering disease of Citrus unshiu Narcov. in Gamagori District, Aichi Pref. Bull. Aichi. Hort. Exp. Sta. 5: 1-9 (In Japanese with English abstract).

Kalonji-M'Buyi and J. Kummert. 1982. Influence of wetting agents on the viro-inhibitory effect on Virazole ${ }^{\circledR}$ used as foliar spray on cabbage plants inoculated with turnip yellow mosaic virus. Parasitica 38: 75-84.

Kilby, J. M., S. Hopkins, T. M. Venetta, B. DiMassimo, G. A. Cloud, J. Y. Lee, L. Alldredge, E. Hunter, D. Lambert, D. Bolognesi, T. Matthews, M. R. Johnson, M. A. Nowak, G. M. Shaw and M. S. Saag. 1998. Potent suppression of HIV-1 replication in human by T-20, a peptide inhibitor of gp41mediated virus entry. Nat. Med. 4: 1302-1307.

Kusano, N., K. Hirashima, M. Kuwahara, K. Narahara, T. Imamura, T. Mimori, K. Nakahira and K. Torii. 2007. Immunochromatographic assay for simple and rapid detection of Satsuma dwarf virus and related viruses using monoclonal antibodies. J. Gen. Plant Pathol. 73: 66-71.

Mitsuya, H., K. J. Weinhold, P. A. Furman, M. H. S. Clair, S. N. Lehrman, R. C. Gallo, D. Bolognesi, D. W. Barry and S. Broder. 1985. 3'-Azido-3'-deoxythymidine (BW A509U): An antiviral agent that inhibits the infectivity and cytopathic effect of human T-lymphotropic virus type III/ lymphadenopathy-associated virus in vitro. Proc. Natl. Acad.
Sci. USA 82: 7096-7100.

Nomura, A., H. Masui, S. Serizawa and K. Ota. 2000. Survey of indexing for Sastuma dwarf virus and citrus tatter leaf virus of citrus varieties in Shizuoka prefecture. Bull. Shizuoka Citrus Exp. Sta. 29: 31-37.

Öberg, B. 1989. Anitiviral effects of phosphonoformate (PFA, Foscarnet sodium). Pharmacol. Ther. 40: 213-285.

Panattoni, A., F. D. Anna, C. Cristani and E. Triolo. 2007a. Grapevine vitivirus A eradication in Vitis vinifera explants by antiviral drugs and thermotherapy. J. Virol. Methods 146: 129-135.

Panattoni, A., F. D. Anna and E. Triolo. 2007b. Antiviral activity of tiazofurin and mycophenolic acid against Grapevine Leafroll-associated Virus 3 in Vitis vinifera explants. Antiviral Res. 73: 206-211.

Sidwell, R. W., J. H. Huffman, G. P. Khare, L. B. Allen, J. T. Witkowski and R. K. Robins. 1972. Broad-spectrum antiviral activity of Virazole: 1- $\beta$-D-Ribofuranosyl-1,2,4-triazole-3carboxamide. Science 177: 705-706.

Simpkins, I., D. G. A. Walkey and H. A. Neely. 1981. Chemical suppression of virus in cultured plant tissues. Ann. Appl. Biol. 99: 161-169.

Stridh, S. and R. Datema. 1984. Mode of interference of trisodium phosphonoformate (INN: Foscarnet sodium) with influenza virus mRNA synthesis. Virology 135: 293-296.

Stridh, S., E. Helgstrand, B. Lannerö, A. Misiorny, G. Stening and B. Öberg. 1979. The effect of pyrophosphate analogues on influenza virus RNA polymerase and influenza virus multiplication. Arch. Virol. 61: 245-250.

Takahara, T., N. Okudai and S. Kuhara. 1986. Elimination of citrus viruses by the semi-micrografting. Bull. Fruit Tree Res. Stn. D 8: 13-24 (In Japanese with English abstract).

Ushiyama, K. 1982. Investigation on tatter leaf virus infection of citrus in Kanagawa. Bull. Kanagawa Hort. Exp. Sta. 29: 917 (In Japanese with English abstract).

Yates, F. 1984. Tests of significance for 2 X 2 contingency tables. J. R. Statist. Soc. A 147: 426-463. 